\title{
21. STRUCTURES AND MAGNETIC FABRICS FROM THE LOWER SHEETED DIKE COMPLEX OF HOLE 504B REORIENTED USING STABLE MAGNETIC REMANENCE ${ }^{1}$
}

\author{
S.A. Allerton, ${ }^{2}$ A.W. McNeill, ${ }^{3}$ L.B. Stokking, ${ }^{4}$ J.E. Pariso,${ }^{5}$ P. Tartarotti, ${ }^{6}$ F.C. Marton, ${ }^{7}$ and N.N. Pertsev ${ }^{8}$
}

\begin{abstract}
Structural measurements from core from the sheeted dike complex recovered during Ocean Drilling Program Legs 137 and 140 to Hole 504B have been reoriented using the paleomagnetic stable declination. Two dike margins observed in the core restore to an approximately east-west strike, and a steep dip to the north, parallel to the orientation of the Costa Rica Rift. Veins can be divided into two sets. The veins of one set are perpendicular to the dike margins, with a range of dips; these veins are interpreted as cooling fractures, formed by the thermal contraction of the dikes. The veins of the second set are parallel to the dikes, dipping steeply and striking approximately east-west. We suggest that these were formed by hot brines with high fluid pressures generated during dike intrusion by contact of fluids in the host rock with molten lava. Unmineralized fractures in the core probably result from anelastic stress-relaxation when the core is brought to the surface. Two dominant orientations occur: subhorizontal discing fractures, and subvertical fractures, which are subparallel, with a mean strike of $131^{\circ}$, approximately parallel to the minimum horizontal in-situ stress estimated for borehole breakout studies.

The samples have a weak anisotropy of magnetic susceptibility, with a distribution of maximum axes with a dominantly shallow inclination. The origin of this fabric is not clear. In geographic coordinates the maximum axis corresponds closely to the present maximum horizontal stress direction, which suggests that the fabric may result from internal stresses. In sample coordinates the maximum fabric corresponds to the long axis of the core. This suggests that the fabric may be related to the sample, rather than being an inherent petrologic property.
\end{abstract}

\section{INTRODUCTION}

The structure of the sheeted dike complex can illuminate the processes active during accretion and alteration of the oceanic crust. It is axiomatic that dikes in the sheeted dike complex are intruded parallel to the ridge, but this has never been demonstrated in situ. Long-lived hydrothermal systems are thought to be driven by heating at the top of a magma chamber (e.g., Strens and Cann, 1982). The sheeted dike complex thus acts as an important conduit for hydrothermal fluids. The relative orientation of veins will indicate the mechanism of formation and control the fracture permeability of the upper crust. Such information is of fundamental importance for testing and constraining models for fluid flow in the upper crust (Lister, 1974; Strens and Cann, 1982). There is recent evidence from the Juan de Fuca Ridge for short-lived hydrothermalism associated with the lateral intrusion of a dike (Fox, 1993), which suggests that dikes and veins may be intimately related. Observations pertaining to these relationships are likely to be of great significance for models of hydrothermalism within the sheeted dike complex.

Our knowledge of the structure of the sheeted dike complex largely comes from ophiolites (e.g., Troodos [Moores and Vine, 1971; Varga and Moores, 1985; Allerton and Vine, 1991]; Josephine [Harper, 1982]; Bay of Islands [Karson, 1984]). These studies have largely focused on the map-scale structure. Work by Baragar et al. (1990) has

\footnotetext{
'Erzinger, J., Becker, K., Dick, H.J.B., and Stokking, L.B. (Eds.), 1995. Proc. ODP. Sci. Results. 137/140: College Station, TX (Ocean Drilling Program),

Department of Earth Sciences, University of Oxford, Parks Road, Oxford OX1 3PR. United Kingdom.

${ }^{3}$ Geology Department, University of Tasmania, GPO Box 252C, Hobart, Tasmania 7001, Australia.

${ }^{4}$ Ocean Drilling Program, Texas A\&M University Research Park, 1000 Discovery Drive, College Station, TX 77845-9547, U.S.A.

${ }^{5}$ School of Oceanography, University of Washington, Seattle, WA 98195 , U.S.A.

${ }^{6}$ Dipartimento di Geologia, Via Giotto 1, 35137 Padova, Italy. U.S.A.

${ }^{7}$ Department of Geological Sciences, Northwestern University, Evanston, IL 60201,

${ }^{8}$ Institute of Geology of Ore Deposits, Academy of Sciences, 35 Staromonetny, Moscow, 109017, Russia.
}

provided an important framework for models of the intrusion of dikes within the sheeted dike complex.

The sheeted dike complex has been drilled in situ in Deep Sea Drilling Project (DSDP)/Ocean Drilling Program (ODP) Hole 504B. The one specifically structural study (Agar, 1990) of core from this hole considered the evolution of fractures in the upper part of the hole above 1562 mbsf.

In this paper we describe the result of the first attempt to systematically reorient structural and magnetic fabric measurements to their in-situ position using the stable remanence direction for cores recovered from Hole 504B during Legs 137 and 140. We discuss the implications of the results for the evolution of the sheeted dike complex.

\section{GEOLOGICAL SETTING}

Hole 504B is located on 5.9 Ma crust south of the intermediate spreading rate Costa Rica Rift (Fig. 1). It is the deepest borehole in the oceanic basement, penetrating to a depth of $2000 \mathrm{~m}$ below seafloor (mbsf), and represents an important reference section for the oceanic crustal sequence (e.g., Becker et al., 1989).

Rocks cored in Hole 504B during Legs 137 and 140 are massive very fine- to medium-grained diabase (Becker, Foss, et al., 1992; Dick, Erzinger, Stokking, et al., 1992). The diabase units are pervasively, but heterogeneously altered, with the development of small, centimeter-scale patches of intense alteration. The dikes are cut by many small veins that are dominantly filled with chlorite and/or actinolite, but a few veins filled with quartz and epidote also have been recorded. In addition to the veins there are fractures that do not have any mineral coating. No fault rocks have been identified, and it is not considered likely that a major fault has been drilled on these legs. Knowledge of the true orientation of these features can provide some important constraints on the timing and mode of their formation, and can provide estimates of mid-crustal stress conditions.

\section{PALEOMAGNETIC REORIENTATION}

In the absence of a hard-rock orientation tool, one of the few ways available to orient hard-rock cores is by paleomagnetic means. We do 


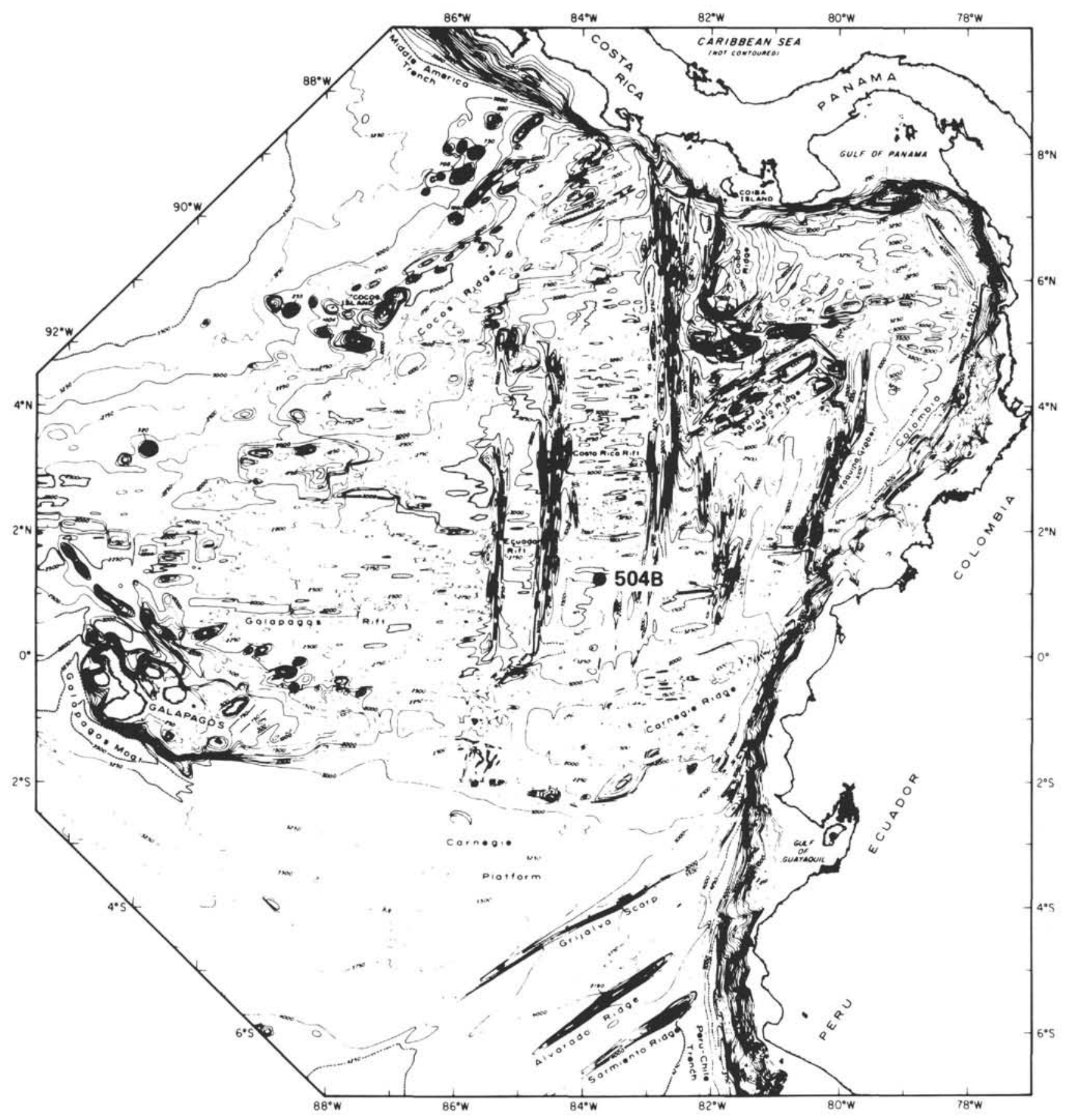

Figure 1. Location of Hole 504B south of the Costa Rica Rift in the eastern equatorial Pacific Ocean (from Lonsdale and Klitgord, 1978).

this by making assumptions about the original orientation of the stable remanence and using magnetic measurements of the stable remanence from minicores to restore individual core pieces to their correct orientation. Structural observations from these pieces can then be related to the "paleomagnetic" reference frame.

The primary assumption we make is that the stable remanence direction was acquired in a reversed field and was originally directed to $180^{\circ}$, so that rotation about a vertical axis is minimal. We base our assumption of a reversed magnetization for the hole on the oceanic magnetic anomaly pattern that places Site 504 in the middle of the C3A magnetic chron (Langseth et al., 1983). It is possible that some lithologic units are normally magnetized, but for the majority the assumption is probably valid. Smith and Banerjee (1986) have de- scribed a secondary magnetization in a few samples in the upper part of the dike sequence, which they used to identify the polarity of the stable remanence component. This yielded approximately equal numbers of reversed and normal polarities, although it was not clear whether this secondary component represented a component acquired in situ, in the Earth's field, or a later viscoremanent contamination. Magnetic logs of the section of interest (Alt, Kinoshita, Stokking, et al., 1993) indicate that normal polarities are rare or nonexistent.

The assumption also precludes any major rotation about a vertical axis. Site 504 was formed at the Costa Rica Rift, approximately equidistant from the two bounding fracture zones, away from regions where strike-slip activity may cause vertical axis rotations (e.g., Allerton and Vine, 1991). The main bathymetric features and magnetic anomalies 
trend toward $093^{\circ}$, approximately parallel to the Costa Rica Rift, again suggesting no large-scale vertical axis rotation. The assumption also does not take account of the effects of secular variation. A large variation is seen in the inclination data, although data from individual units are often tightly clustered, and it has been argued (Allerton et al., this volume) that the stable magnetization is either a thermal remanence or a rapidly acquired chemical remanence that does not average out secular variation. This may produce a declination error of about $17^{\circ}$ estimated from McFadden et al. (1988). This is similar to the standard deviation of the stable inclination of the sheeted dike complex $\left(\sim 23^{\circ}\right.$, Smith and Banerjee, 1986; 17 ${ }^{\circ}$, Dick, Erzinger, Stokking, et al., 1992). We consider that this controls the precision of our reorientations. We will also argue that the consistency of our reoriented directions gives us additional confidence in the technique.

Structural features were measured in the core using the method described in Dick, Erzinger, Stokking, et al., 1992. Measuring orientations in core drilled in a vertical borehole introduces a sampling bias in favor of shallow-dipping planes, discussed by Newmark et al. (1985a). The deviations of the borehole from vertical are of significance to measurements of the relative inclinations of features observed in the core. Borehole deviation was measured using the caliper $\log$ and the inclinometry section of the Formation MicroScanner (FMS) run on Leg 148 at Hole 504B (Alt, Kinoshita, Stokking, et al., 1993). In the section of interest between 1500 and 2000 mbsf, the deviation of the borehole from the vertical gradually increases from about $2^{\circ}$ to $5^{\circ}$ to the northeast. The errors introduced to the orientation of individual measurements by deviation of the borehole from vertical are small enough, in comparison with errors associated with paleomagnetic reorientation, to be negligible.

Structural observations from individual pieces of core that had been sampled for paleomagnetism were reoriented using the declination of the stable remanence. Where multiple samples were taken from a single piece of core, a mean declination was used. In total, the orientation of 572 structural features has been measured in the core between $1570 \mathrm{mbsf}$ and $1984 \mathrm{mbsf}$. Of these, 139 observations have been reoriented using the paleomagnetic remanence.

\section{Nature of Magnetic Remanence}

The nature of the remanent magnetism of samples recorded on Legs 137 and 140 has been reported fully in Dick, Erzinger, Stokking, et al. (1992); Allerton et al. (this volume; ) and Pariso et al. (this volume). The natural remanent magnetization (NRM) of the samples can be resolved into two components: a steeply inclined, low coercivity $(<20 \mathrm{mT})$, low unblocking temperature $\left(<400^{\circ} \mathrm{C}\right)$ component, which is considered to be a drilling-induced effect; and a shallow, stable component, with coercivities between 0 and $100 \mathrm{mT}$, and unblocking temperatures between about $400^{\circ} \mathrm{C}$ and $585^{\circ} \mathrm{C}$. Magnetite is the dominant carrier in these rocks. No shallow inclination secondary components such as those described by Smith and Banerjee (1986) were identified in the samples acquired on Legs 137 and 140, because the low-coercivity fractions were dominated by the drilling remanence.

Analysis of the inclination data and modelling of the components (Allerton, et al., this volume) suggest that the stable component was acquired relatively rapidly following cooling and either represents a thermal remanent magnetization (TRM) or a rapidly acquired chemical remanent magnetization (CRM). This result is consistent with other observations of magnetic properties and oxide petrography (Pariso et al., this volume).

\section{REORIENTATION OF STRUCTURAL OBSERVATIONS}

\section{Fractures}

Fracturing is ubiquitous throughout core recovered from the lower part of the dike sequence. The fractures lack any mineral filling, by definition (in contrast to veins, which are filled), and form two types,

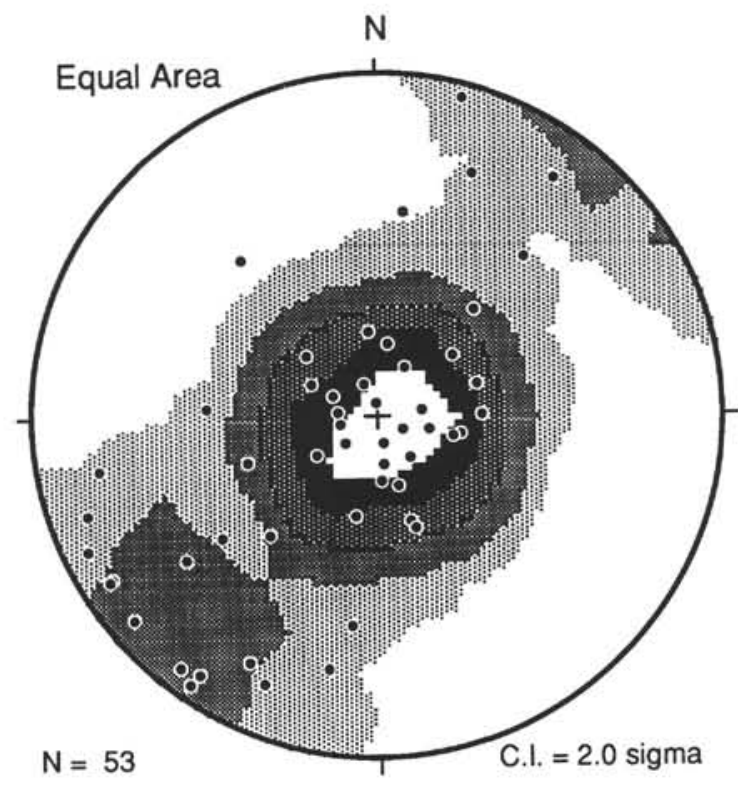

Figure 2. Poles to fractures measured in core, reoriented to the paleomagnetic reference, superimposed on a Kamb contour plot of the same data. Equal-area lower hemisphere projection. C.I. = contour interval, $\mathrm{N}=$ number of measurements. Note that this corrected plot is the mirror image of the plot of the same data published in Dick, Erzinger, Stokking, et al. (1992).

incipient and well developed. They appear white in hand specimen and have thicknesses $<0.2 \mathrm{~mm}$. Many of these fractures appear during the first few hours after the cores have been brought to the surface. Two sets can be defined by their orientation (Fig. 2). The majority are evenly distributed, subhorizontal fractures, which may be equivalent to disking fractures described in other deep boreholes (Wolter et al., 1990). In addition, steeply inclined fractures occur, some of which have been reoriented using the stable remanence. There is some degree of overlap between these two distributions. The subvertical set is restored to a relatively tight distribution, with a mean strike of $131^{\circ} \pm 13^{\circ}\left(\alpha_{95}\right.$ cone of confidence). These features are interpreted as extension fractures resulting from the release of stored anelastic strain. While the core is in situ, it is acted on by external tectonic stresses. These are balanced by internal (elastic and anelastic) stresses; otherwise the core would be infinitely compressible (Fig. 3A). When the core is drilled and brought to the surface, the external tectonic stress is removed; the stress affecting the core is the residual, anelastic component of the internal stress (Fig. 3B). Fractures will form if the maximum internal stress (now tensional) is greater than the tensile strength. Their tensional nature may indicate that these residual, anelastic stresses largely originate from thermal contraction. They will form perpendicular to the maximum extensional internal stress in the core at the surface, which corresponds to the maximum horizontal compressive stress in situ ( $\mathrm{SH})$ $\left(041^{\circ} \pm 13^{\circ}\right)$. Independent estimates of the in-situ stress have been made from borehole televiewer measurements, which give $\mathrm{SH}$ directions as $020^{\circ} \pm 16^{\circ}$ (Newmark et al., 1985b) and $032^{\circ}$ (Morin et al., 1990). The consistency of these estimates adds confidence to our use of the stable magnetic direction to reorient the cores and strengthens the interpretation of the vertical fractures as a strain-release phenomenon.

\section{Dike Margins}

Dike margins were observed in two oriented pieces from core recovered during Leg 140 (Fig. 4). These were sampled for paleomagnetic analysis, and the dikes were restored to dip $79^{\circ}$ toward $356^{\circ}$ and $\operatorname{dip} 84^{\circ}$ toward $016^{\circ}$. These results suggest that the dikes dip steeply to the north and strike approximately east-west, parallel to the Costa Rica Rift, and parallel to the local magnetic anomaly and bathymetric trends. 
Figure 3. Stresses in core, showing the relative orientations of stresses acting on the core, and a Mohr diagram illustrating the relative stresses. A. In-situ within the borehole. B. At surface, showing the conditions of failure.

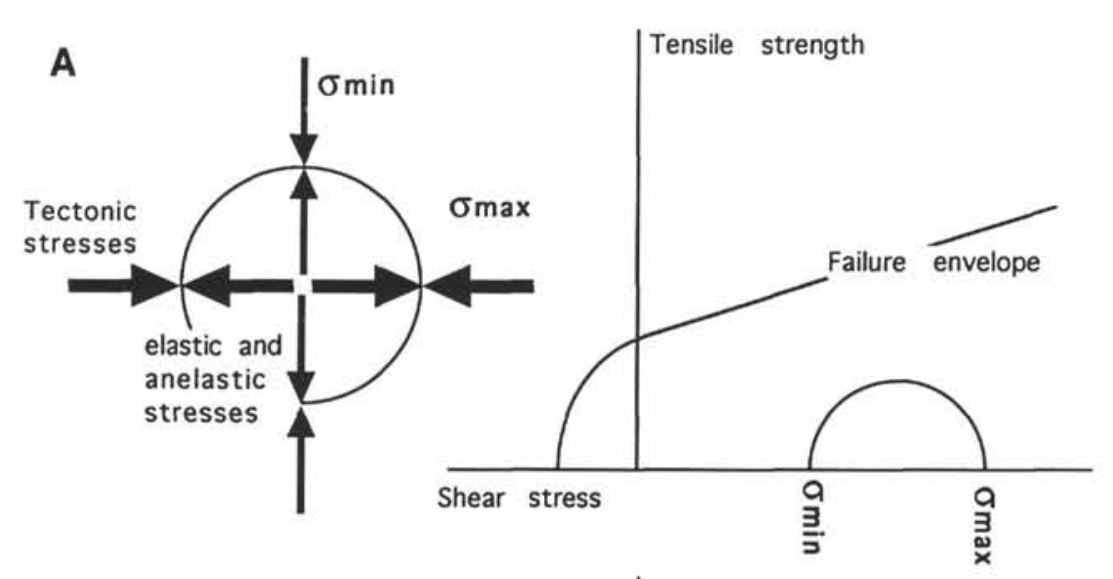

B

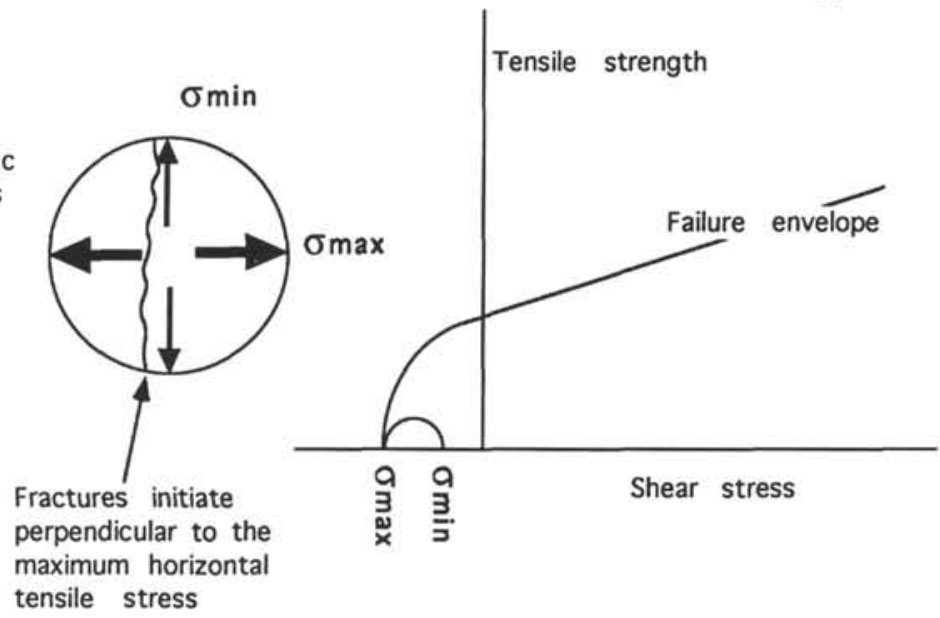

We prefer the former option, as the extreme heating associated with the intrusion of dikes is likely to produce locally the high fluid pressures needed to generate extensional fractures (Fig. 7). A similar relationship is observed in the Skaergaard intrusion in East Greenland, where chlorite veins are intimately associated with the intrusion of mafic dikes (Rogers and Bird, 1987).

A simple estimate of the fluid pressures before and after contact with a molten dike can be made. We assume that before the dike is intruded the brines in the host rock and the host rock itself are in equilibrium at about $350^{\circ} \mathrm{C}$, and at about $100 \mathrm{MPa}$. The dike is intruded at the solidus temperature $\left(\sim 1100^{\circ} \mathrm{C}\right)$. Initially thermal contraction of the dike is accommodated by viscous flow (e.g., Lister, 1974), and heat is dissipated by convection, so that the temperature at the dike margin is midway between the host-rock temperature and the dike intrusion temperature (Jaeger, 1968) (that is, $\sim 700^{\circ} \mathrm{C}$ ). If the effect of the latent heat of crystallization is considered, this temperature may rise to $\sim 900^{\circ} \mathrm{C}$. If the brines at the dike margin also rise to this temperature, then their new pressure state can be estimated from the equation of state for water (Burnham et al., 1969), assuming that the volume remains unchanged. The new pressures are between 500 $\mathrm{MPa}$ and $700 \mathrm{MPa}$, much greater than the sum of the lithostatic stress $(\sim 100 \mathrm{MPa})$ and the breaking strength of diabase ( 40 MPa, Frederick Diabase [Jaeger and Cook, 1969]), suggesting that hydraulic fracturing and vein formation would occur.

The Group 2 veins are approximately orthogonal to the dike margins, with a wide range of dips, and are interpreted as contractional cooling fractures, which migrate from the cooler margins toward the centers of the dikes. As the cracking front migrates, it sucks fluids from the cooler host dikes. The veins act as important pathways for the migration of fluids that pervasively alter the adjacent cooling dike material. Amphibole vein-filling minerals start to precipitate at temperatures of $400^{\circ}-500^{\circ} \mathrm{C}$ (D. Vanko, pers. comm., 1993). As the tem- 


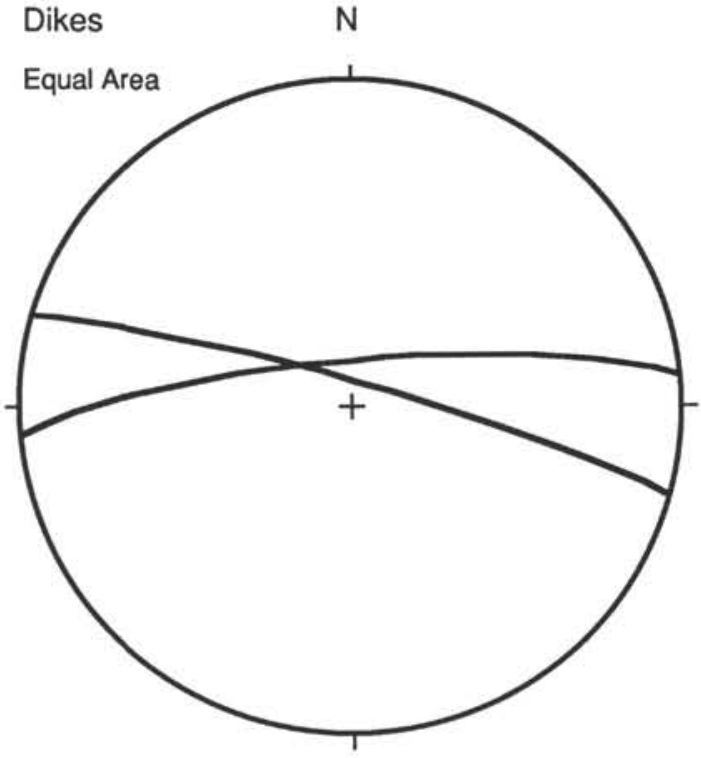

Figure 4. Dikes measured in the core, reoriented to the paleomagnetic reference. Great circles on an equal-area lower hemisphere projection.

perature of the vein fluids decreases, the fluid pressures also decrease, allowing the veins to seal, and producing compressional deformation of the vein-filling minerals (e.g., Tartarotti et al., this volume).

Lister (1974) stresses the importance of hydro-fracturing as a process in the oceanic crust. He envisages a general downward propagation of fluids into the hot rock beneath. The orientation of Group 2 cooling fractures we observe is more consistent with the lateral propagation of cracks and flow of fluids from the dike margins to their centers. This emphasizes that molten dikes are intruded into cooler, relatively wet, earlier host dikes (also obvious from the chilled margins of the dikes). Dikes would be expected to cool relatively rapidly after intrusion, providing a pulse of superheated brine into the hydrothermal flow system. This model is consistent with the occurrence of a recent episode of hydrothermal activity and dike intrusion monitored on the Juan de Fuca Ridge by the migration of small tremors on a seismo-acoustic network (Fox, 1993).

This model of formation suggests that in any one dike, Group 2 cooling veins would form first, and then be cut by later, Group 1, dikeparallel veins. In this cycle the dike-parallel veins form first (Figs. 6 and 7), as the dike is intruded, followed by the dike-orthogonal veins, which form as the dike cools. Yet, as the dike-parallel veins cut only the host rock, not the new dike, these veins cut the dike-orthogonal cooling veins of the earlier, host dikes. This is consistent with the observation that steep veins generally cut shallow veins associated with the intrusion of another dike. It also has significant implications both for the timing of vein formation and the nature of the vein-filling fluids. This sequence also may allow relatively late-stage dikes to be identified, as these would be expected to have far fewer dike-parallel veins associated with them.

This model for the development of the veins has implications for the fracture permeability of the oceanic crust. The dike-orthogonal veins are restricted to individual dikes, because they form as the dikes cool. In contrast, the dike-parallel veins are not restricted to individual dikes, will cut dike boundaries, and be generally more through-going fractures. These veins will be linked by short, dike-orthogonal veins, producing a ridge-parallel flow regime, as has been assumed in numerous models of hydrothermal circulation (e.g., Strens and Cann, 1982).

\section{MAGNETIC FABRICS}

The magnitude and direction of the ellipsoid of anisotropy of magnetic susceptibility (AMS) gives a measure of the orientation of

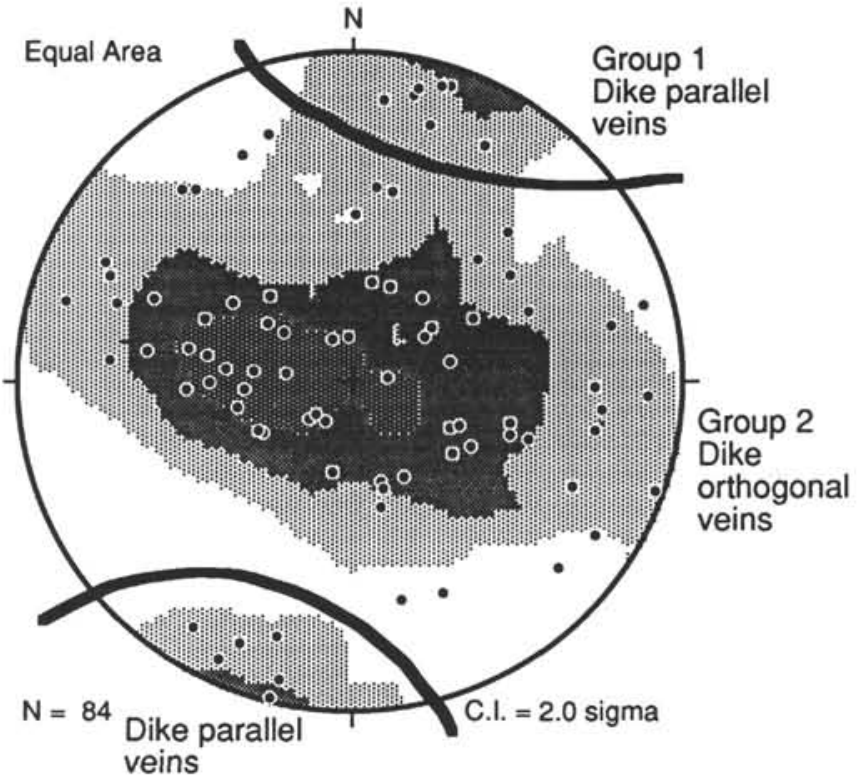

Figure 5. Poles to veins measured in core, reoriented to the paleomagnetic reference, superimposed on a Kamb contour plot of the same data. Equal-area lower hemisphere projection. C.I. = contour interval, $\mathrm{N}=$ number of measurements. Note that this corrected plot is the mirror image of the plot of the same data published in Dick, Erzinger, Stokking, et al. (1992).

the magnetic grains in the rock. The preferred orientation of the magnetic grains has been used to indicate the flow direction in intrusive and extrusive igneous bodies (Ellwood, 1978) and more specifically to give flow directions in dikes in ophiolites (e.g., Rochette et al., 1990; Staudigel et al., 1992). It also has been related to internal stresses resulting from thermal contraction (e.g., Ellwood and Fisk, 1977), which may be considerable in these rocks. AMS fabrics also have been related to strains in deformed rocks (e.g., Hrouda, 1976), although such an origin is considered unlikely in these rocks, which show no strain fabric in thin section.

We present here measurements of AMS on 64 minicores measured at Oxford and Scripps, both using a KLY-2 susceptibility bridge. Knight and Walker (1988) and Staudigel et al. (1992) have emphasized the need to take samples from dike margins for flow-fabric studies. In this investigation it was not possible to sample dike margins exclusively, because few margins were recovered in pieces large enough to take a paleomagnetic sample.

Although the degree of anisotropy $\left(\left[\mathrm{K}_{\max } / \mathrm{K}_{\min }\right] \cdot 100 \%\right)$ recorded in these rocks is small $(<5 \%$, Fig. 8$)$, the precision and repeatability of the measurements is high. For the majority of the samples (39) the AMS measurements were conducted before demagnetization, but some (25) were shipboard samples that were demagnetized by AF cleaning on the drill ship before AMS fabric was determined. The sequence of measurement is important because the application of a static alternating field can impress an anisotropy (Potter and Stephenson, 1990), an effect we have been able to reproduce in some of these samples. For this reason we have excluded the shipboard samples from our discussion of the AMS fabrics.

There is marginally less scatter on the maximum anisotropy axis in sample coordinates (Fig. 9A) than in geographic coordinates (Fig. 9B), although this has not been demonstrated to be statistically significant.

In geographic coordinates the minimum axes of susceptibility are highly scattered, but with a dominance of steep inclinations. The maximum axes define a subhorizontal girdle, with a maximum directed toward $137^{\circ}$ after correction. This maximum direction is offset from the strike of the dikes and of the ridge axis by about $50^{\circ}$. It does, however, align quite closely with the estimate of the minimum principal stress axis derived from borehole breakout measurements (e.g., 


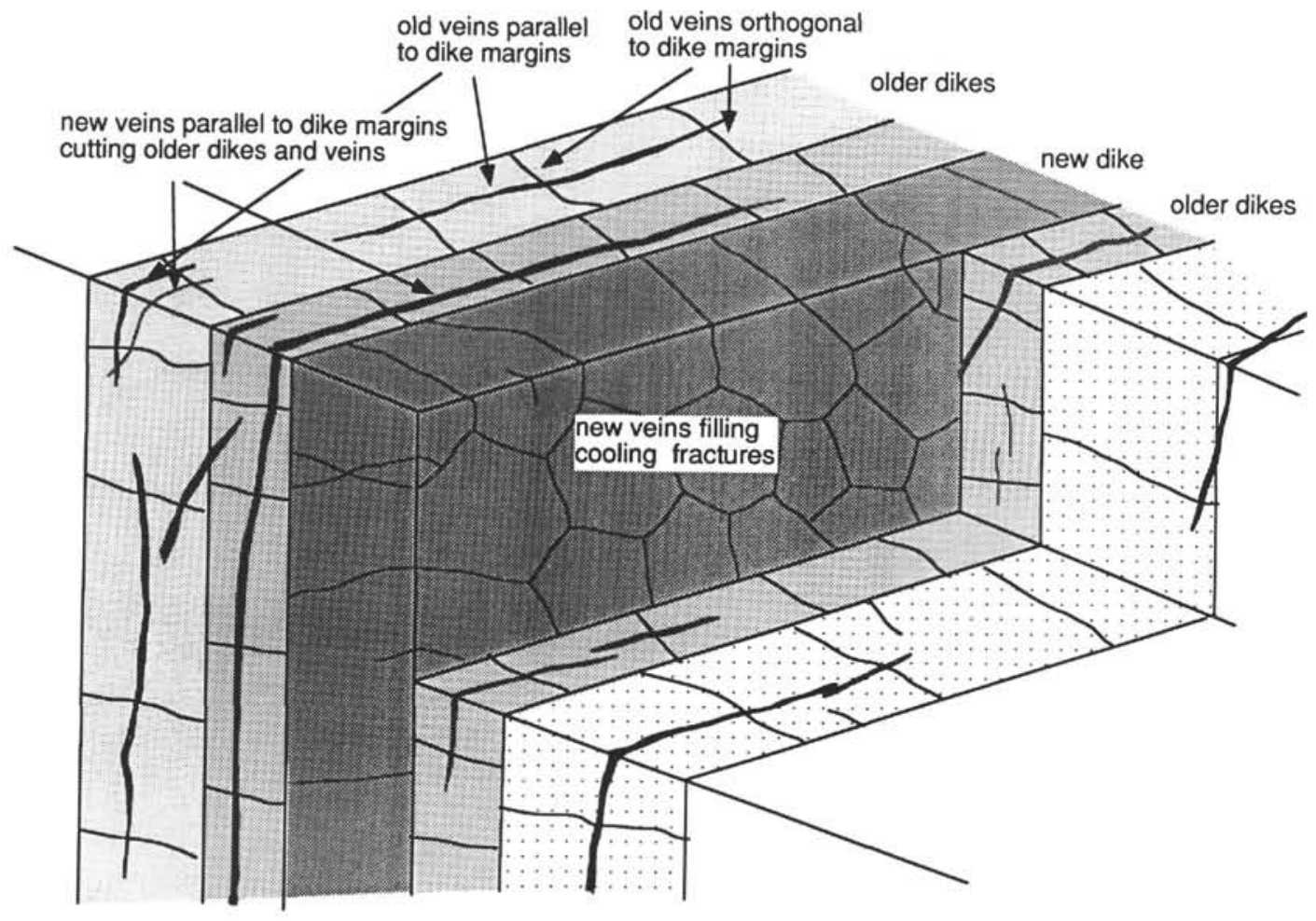

Figure 6. Cartoon illustrating the relative orientations of the dikes and the two sets of veins.

A Dike-parallel veins

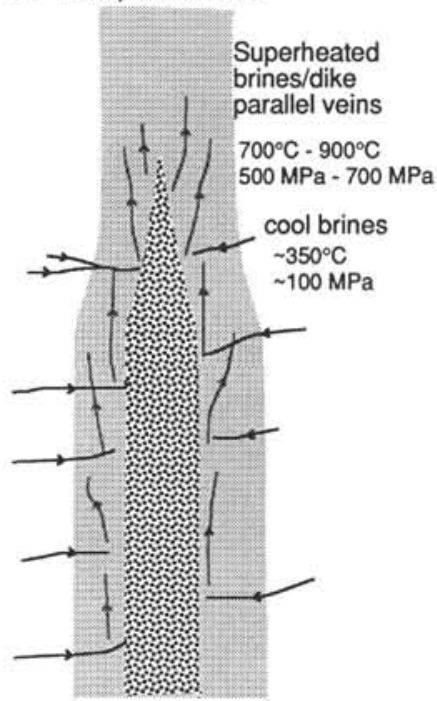

B Dike-orthogonal veins (cooling fractures)

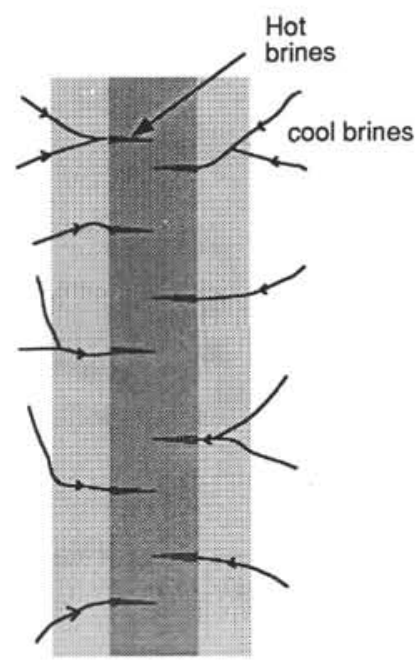

Figure 7. Cartoon illustrating the relationship between the intrusion of dikes and accompanying formation of veins. A. Dike-parallel (Group 1) veins form by hydraulic fracturing as, or soon after, the dike has been intruded; the high fluid pressures are generated by the extreme heating following contact between formation fluids and the molten dike. B. Dike-orthogonal (Group 2) veins form as the dikes cool, solidify, and contract. Hydrofracturing (e.g., Lister, 1984) accelerates this process.

Morin et al., 1990). This distribution of AMS fabrics also has been observed in shipboard AMS measurements derived on Leg 148 both from extrusives in Hole 896A and sheeted dikes in Hole 504B (Alt, Kinoshita, Stokking, et al., 1993) where, given the range of lithologies, a magmatic flow origin for the fabric is not considered likely. The relation between the in-situ stress orientation and the maximum

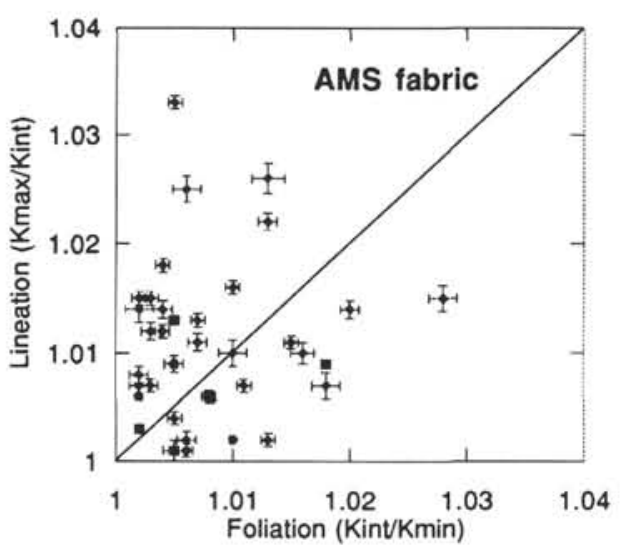

Figure 8. Anisotropy of magnetic susceptibility; lineation $\left(\mathrm{K}_{\max } / \mathrm{K}_{\text {int }}\right)$ vs. foliation $\left(\mathrm{K}_{\mathrm{int}} / \mathrm{K}_{\text {min }}\right)$. Error bars are $2 \times$ standard errors.

AMS axis may reflect a stress-related origin for the magnetic fabric. The stress-release fracturing observed in the core after it has been brought to the surface indicates that the core is in tension, at least in the direction parallel to the observed $\mathrm{K}_{\max }$ axis. The effects of tensional stresses on magnetic anisotropy have not been described, although uniaxial pressure generates a decrease in susceptibility in the direction of maximum stress that, for multidomain grains, results from modification of the domain pattern (Kapicka, 1990). It is feasible that differences in internal stresses-sufficient to fracture the core - can create the susceptibility anisotropy observed in the samples. This is different from the mechanism proposed by Ellwood and Fisk (1977), who related the fabric to thermal stresses active before complete solidification of the melt, which would, by analogy, require the long axis of the fabric to be in the plane of the dike.

In sample coordinates the maximum axes are distributed about an axis parallel to the long axis of the sample, which suggests that the fabric measured in these rocks may be dependent on the orientation 


\section{A}

Kmax Before Correction (Sample coordinates)

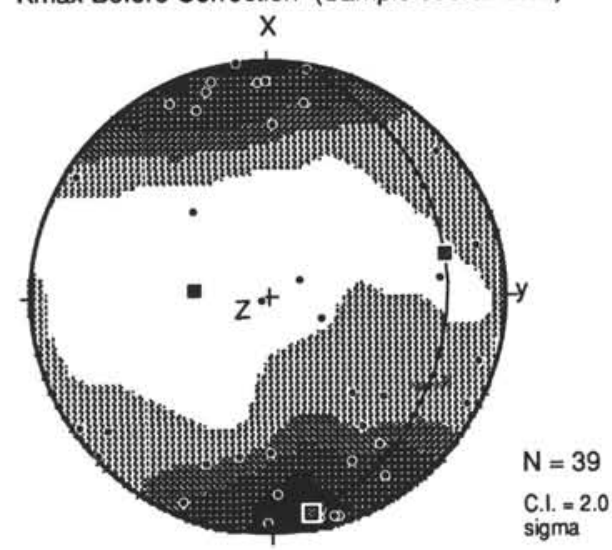

B Kmax After Correction (Geographic coordinates)

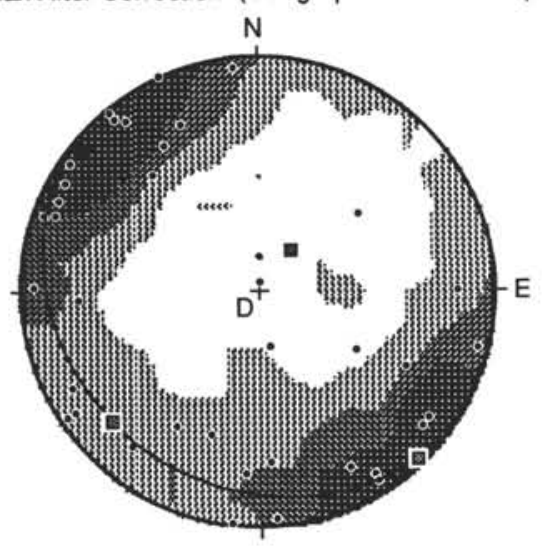

Kmin Before Correction (Sample coordinates)

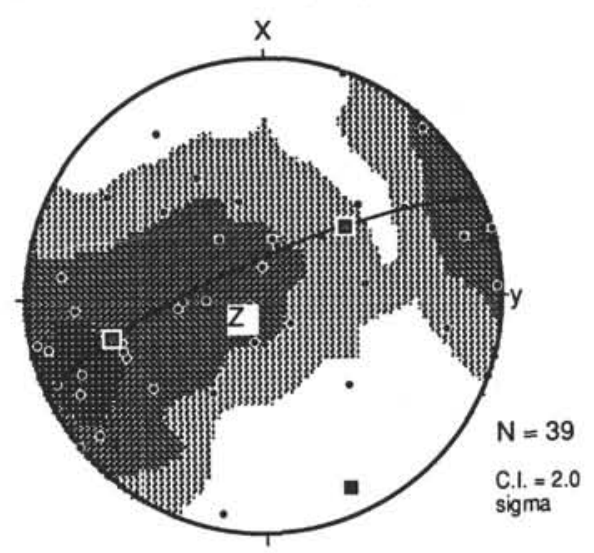

Kmin After Correction (Geographic coordinates)

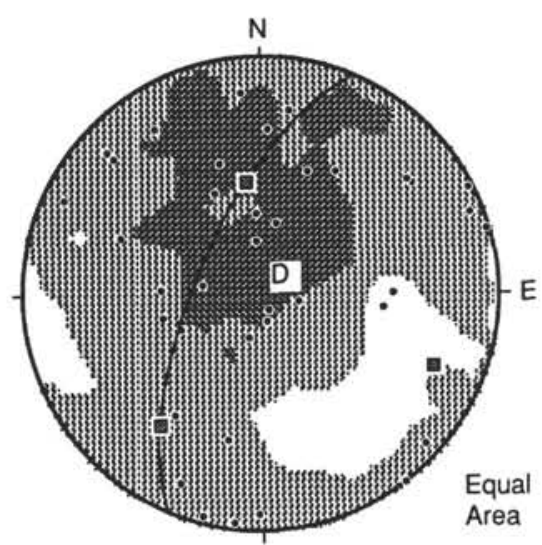

Figure 9. Anisotropy of magnetic susceptibility: Principal (maximum $-K_{\max }$, minimum $-K_{\min }$ ) axes of magnetic susceptibility measured in core, superimposed on a Kamb contour plot of the same data. Equal-area lower hemisphere projection. C.I. = contour interval, $\mathrm{N}=$ number of measurements. A. Before reorientation to the paleomagnetic reference. B. After reorientation to the paleomagnetic reference.

or shape of the sample. The possibility that this represents a shape anisotropy has been addressed. The length/diameter $(\mathrm{l} / \mathrm{d})$ ratios have been compared to the degree of linearity; no correlation has been identified. Even samples with ratios less than the ideal ratio for AMS samples ( $\mathrm{l} / \mathrm{d}=0.90$; Collinson, 1983) give the same long axis-parallel fabric. The fabric may be a stress-release phenomenon, as the cores are drilled into the cut face of the core, which may be expected to have suffered some anelastic rebound and stress release orthogonal to the cut face and parallel to the long axis of the core.

Clearly no firm conclusions can yet be drawn about the origin of this fabric. It does not seem to be simply related to flow during intrusion, or to thermal stresses present during solidification; neither is it dependent on the dimensions of the sample. It is possible that the fabric is the result of more than one effect. An interesting possibility is that it is reflecting the internal state of stress in the sample, either due to anelastic thermal stresses generated in the borehole, or by some stress-release effect after the core has been sliced.

\section{DISCUSSION \\ Overall Structure}

The two dike margins recorded in the core dip steeply to the north, approximately parallel to the steep vein sets. If the dikes and the veins were initially vertical, this would suggest that the sequence has been tilted $5^{\circ}-10^{\circ}$ to the south-that is, away from the ridge axis. This structure is also suggested from single channel seismic reflection profiles (Langseth et al., 1988), which show an asymmetric basement topography with long, shallow-dipping $\left(\sim 5^{\circ}\right)$ south-facing slopes and steep, short, north-facing slopes; this suggests normal fault-bounded half-graben. These north-dipping normal faults are obscured by reflection hyperbolae, so the dips cannot be estimated with any precision. There is some indication of disturbance of the sediments above the faults, indicating that the faults may have reactivated after the sediments were deposited, away from the axial valley walls. This structural grain also has been described by Searle (1983) from Gloria side-scan sonar data closer to the axis, where the faults are not obscured by sedimentary cover.

\section{CONCLUSION}

Dikes were intruded parallel to the spreading axis and tilted from vertical to $80^{\circ}-85^{\circ} \mathrm{N}$. Veins can be separated into two sets. One set is parallel to the dikes and may have formed during dike intrusion; the other set is orthogonal to the dikes and probably represents mineralized cooling fractures. This network of veins-long, continuous veins parallel to the ridge axis and short veins orthogonal to the dikes-will control the fracture permeability in the sheeted dike complex. The sequence tilts gently to the south, probably resulting from rotation of the footwall of the valley-wall faults immediately to the south.

Vertical fractures have a mean strike of $131^{\circ} \pm 13^{\circ}$ and are interpreted as originating as extensional fractures resulting from the release of stored elastic strain.

Magnetic (AMS) fabrics have a maximum axis of anisotropy that is dominantly subhorizontal, with a mean direction toward the long 
axis of the core and $137^{\circ}$ in geographic coordinates, subparallel to the minimum in-situ stress. This fabric may be related to the internal stress within the sample.

\section{ACKNOWLEDGMENTS}

We would like to thank Fred Vine and Jeff Gee for careful reviews that significantly improved this manuscript. We also acknowledge discussion with members of the Leg 137 and 140 scientific parties. Special thanks to the officers and crew of the JOIDES Resolution, and to the SEDCO drillers and ODP technicians for making Leg 140 successful and enjoyable.

\section{REFERENCES*}

Agar, S.M., 1990. Fracture evolution in the upper ocean crust: evidence from DSDP Hole 504B. In Knipe, R.J., and Rutter, E.H. (Eds.), Deformation Mechanisms, Rheology and Tectonics. Geol. Soc. Spec. Publ. London, 54:41-50.

Allerton, S., and Vine, F.J., 1991. Spreading evolution of the Troodos ophiolite, Cyprus. Geology, 19:637-640.

Alt, J.C., Kinoshita, H., Stokking, L.B., et al., 1993. Proc. ODP, Init. Repts., 148: College Station, TX (Ocean Drilling Program).

Baragar, W.R.A., Lambert, M.B., Baglow, N., and Gibson, I.L., 1990. The sheeted dike zone in the Troodos ophiolite. In Malpas, J., Moores, E.M., Panayiotou, A., and Xenophontos, C. (Eds.), Ophiolites: Oceanic Crustal Analogues. Cyprus Geol. Surv. Dep., Min. Agr. Nat. Res., 37-51.

Becker, K., Foss, G., et al., 1992. Proc. ODP, Init. Repts., 137; College Station, TX (Ocean Drilling Program).

Becker, K., Sakai, H., Adamson, A.C., Alexandrovich, J., Alt, J.C., Anderson, R.N., Bideau, D., Gable, R., Herzig, P.M., Houghton, S.D., Ishizuka, H., Kawahata, H., Kinoshita, H., Langseth, M.G., Lovell, M.A., Malpas, J., Masuda, H., Merrill, R.B., Morin, R.H., Mottl, M.J., Pariso, J.E., Pezard, P.A., Phillips, J.D., Sparks, J.W., and Uhlig, S., 1989. Drilling deep into young oceanic crust, Hole 504B, Costa Rica Rift. Rev. Geophys., 27:79102.

Burnham, C.W., Holloway, J.R., and Davis, N.F., 1969. The specific volume of water in the range 1000 to 8900 bars, 20 degrees to 900 degrees C. Am. J. Sci., 267A:70-95.

Collinson, D.W., 1983. Methods in Rock Magnetism and Palaeomagnetism: Techniques and Instrumentation: London (Chapman and Hall).

Dick, H.J.B., Erzinger, J., Stokking, L.B., et al., 1992. Proc. ODP, Init. Repts., 140: College Station, TX (Ocean Drilling Program).

Ellwood, B.B., 1978. Flow and emplacement direction determined for selected basaltic bodies using magnetic susceptibility anisotropy measurements. Earth Planet. Sci. Lett., 41:254-264.

Ellwood, B.B., and Fisk, M.R., 1977. Anisotropy of magnetic susceptibility variations in a single lcelandic columnar basalt. Earth Planet. Sci. Lett., $35: 116-122$.

Fox, C.G., 1993. Real-time detection of a volcanic eruption on the Juan de Fuca Ridge using the U.S. Navy Sound Surveillance System. Eos, 74:619.

Harper, G.D., 1982. Evidence for large-scale rotations at spreading centres from the Josephine ophiolite. Tectonophysics, 82:25-44.

Hrouda, F., 1976. A model for the orientation process of ferromagnetic minerals in slates. Earth Planet. Sci. Lett., 33:107-110.

Jaeger, J.C., 1968. Cooling and solidification of igneous rocks. In Hess, H.H., and Poldervaart, A. (Eds.), Basalts: The Poldervaart Treatise on Rocks of Basaltic Composition (2nd ed.): New York (Wiley), 503-536.

Jaeger, J.C., and Cook, N.G.W., 1969. Fundamentals of Rock Mechanics: New York (Chapman and Hall).

Kapicka, A., 1990. Variations of the mean susceptibility of rocks under hydrostatic and non-hydrostatic pressure. Phys. Earth. Planet. Inter., 63:78-84.

Karson, J.A., 1984. Variations in structure and petrology in the Coastal Complex, Newfoundland: anatomy of an oceanic fracture zone. In Gass, I.G., Lippard, S.J., and Shelton, A.W. (Eds.), Ophiolites and Oceanic Lithosphere. Geol. Soc. Spec. Publ. London, 13:131-144.

Knight, M.D., and Walker, G.P.L., 1988. Magma flow directions in dikes of the Koolau complex, Oahu, determined from magnetic fabric studies. $J$. Geophys. Res., 93:4301-4319.
Langseth, M.G., Cann, J.R., Natland, J.H., and Hobart, M., 1983. Geothermal phenomena at the Costa Rica Rift: background and objectives for drilling at Deep Sea Drilling Project Sites 501, 504, and 505. In Cann, J.R., Langseth, M.G., Honnorez, J., Von Herzen, R.P., White, S.M., et al., Init. Repts. DSDP, 69: Washington (U.S. Govt. Printing Office), 5-29.

Langseth, M.G., Mottl, M.J., Hobart, M.A., and Fisher, A., 1988. The distribution of geothermal and geochemical gradients near Site 501/504: implications for hydrothermal circulation in the oceanic crust. $n$ Becker, K., Sakai, H., et al., Proc. ODP, Init. Repts., 111: College Station, TX (Ocean Drilling Program), 23-32.

Lister, C.R.B., 1974. On the penetration of water into hot rock. Geophys. J. R. Astron. Soc., 39:465-509.

Lonsdale, P., and Klitgord, K.D., 1978. Structure and tectonic history of the eastern Panama Basin. Geol. Soc. Am. Bull., 89:981-999.

McFadden, P.L., Merrill, R.T., and McElhinny, M.W., 1988. Dipole/quadrupole family modeling of paleosecular variation. J. Geophys. Res., 93:11583-11588.

Moores, E.M., and Vine, F.J., 1971. The Troodos Massif, Cyprus and other ophiolites as oceanic crust: evaluation and implications. Philos. Trans. $R$. Soc. London, A, 268:443-466.

Morin, R., Gable, R., and Becker, K., 1990. State of lithospheric stress and borehole stability at DSDP Site 504, eastern equatorial Pacific. J. Geophys. Res., 95:9293-9303.

Newmark, R.L., Anderson, R.N., Moos, D., and Zoback, M.D., 1985a. Sonic and ultrasonic logging of Hole 504B and its implications for the structure, porosity, and stress regime of the upper $1 \mathrm{~km}$ of the oceanic crust. In Anderson, R.N., Honnorez, J., Becker, K., et al., Init. Repts. DSDP, 83: Washington (U.S. Govt. Printing Office), 479-510.

Newmark, R.L., Zoback, M.D., and Anderson, R.N., 1985b. Orientation of in situ stresses near the Costa Rica Rift and Peru-Chile Trench, Deep Sea Drilling Project Hole 504B. In Anderson, R.N., Honnorez, J., Becker, K., et al., Init. Repts. DSDP, 83: Washington (U.S. Govt. Printing Office), 511-514.

Potter, D.K., and Stephenson, A., 1990. Field-impressed anisotropies of magnetic susceptibility and remanence in minerals. J. Geophys. Res. 95:15573-15588.

Rochette, P., Jenatton, L., Dupuy, C., Boudier, F., and Reuber, I., 1990. Emplacement mode of basaltic dikes in the Oman ophiolite: evidences from magnetic anisotropy with reference to geochemical studies. Proc. Oman Ophiolite Symp.

Rogers, R.D., and Bird, D.K., 1987. Fracture propagation associated with dike emplacement at the Skaergaard intrusion, East Greenland. J. Struct. Geol., 9:71-86.

Searle, R.C., 1983. Gloria survey over Costa Rica Rift Sites 501, 504, and 505. In Cann, J.R., Langseth, M.G., Honnorez, J., Von Herzen, R.P., White, S.M., et al., Init. Repts. DSDP, 69: Washington (U.S. Govt. Printing Office), 217-222.

Smith, G.M., and Banerjee, S.K., 1986. Magnetic structure of the upper kilometer of the marine crust at Deep Sea Drilling Project Hole 504B, eastern Pacific Ocean. J. Geophys. Res., 91:10337-10354.

Staudigel, H., Gee, J., Tauxe, L., and Varga, R.J., 1992. Shallow intrusive directions of sheeted dikes in the Troodos ophiolite: anisotropy of magnetic susceptibility and structural data. Geology, 20:841-844.

Strens, M.R., and Cann, J.R., 1982. A model of hydrothermal circulation in fault zones at mid-ocean ridge crests. Geophys. J. R. Astron. Soc., 71:225240.

Varga, R.J., and Moores, E.M., 1985. Spreading structure of the Troodos ophiolite, Cyprus. Geology, 13:846-850.

Wolter, K.E., Roeckel, T., et al., 1990. Core disking in KTB drill cores and the determination of the in-situ stress orientation. In Emmermann, R., Dietrich, H.-G., et al. (Eds.), Pilot Hole, Results of Geoscientific Investigation in the KTB Field Laboratory, 0-4000. Im. KTB Rep. 90-8:G1-G13.

\footnotetext{
Abbreviations for names of organizations and publications in ODP reference lists follow the style given in Chemical Abstracts Service Source Index (published by American Chemical Society).
}

\footnotetext{
Date of initial receipt: 11 August 1993

Date of acceptance: 2 February 1994

Ms 137/140SR-027 